\title{
Evaluation of Wastewater Treatment Plant Efficiency and Suitability of Treated Wastewater for Irrigation Purposes at Sirte city, Libya
}

\author{
Ramadan Ali Milad \\ Department of Soil and Water, University of Sirte, Libya \\ Corresponding author: Ramdan Ali Milad, e -mail: sirtgirl69@yahoo.com
}

\begin{abstract}
This study aims to evaluate the efficiency of wastewater treatment plant and the quality of treated wastewater for irrigation purposes at Sirte city in Libya, during November 2012. Samples of wastewater were collected before and after treatment at 8 am and $4 \mathrm{pm}$ of the each day of November. The official methods were followed in collection and analysis of the wastewater samples. The average values of purification efficiency were varied across the measured parameters, where as the lowest and highest values of purification percentage were $3.16 \%$ and $33.45 \%$, recorded for phosphorus $(\mathrm{P})$ and bicarbonates $\left(\mathrm{HCO}_{3}\right)$, respectively. On the other hand, the values of $\mathrm{pH}$ and chloride were increased by $5 \%$ and $33 \%$ after treatment, respectively. The most parameters of treated wastewater were found to conform to FAO standards for irrigation water. However, the electrical conductivity $(\mathrm{EC})$, chloride $(\mathrm{Cl})$, sulfate $\left(\mathrm{SO}_{4}\right)$, chromium, manganese and molybdenum were found exceeding the severe restriction zone according to FAO standards. The study concluded that using of treated wastewater of Sirte plant for irrigation purposes need appropriates soil-water-crop management strategies as to be used safely.
\end{abstract}

Keywords: Wastewater, Water Quality, Efficiency, Irrigation, Purification

\section{INTRODUCTION}

In many arid and semi-arid areas water is becoming an increasingly scarce resource and the planners are forced to consider any source of water which might be used economically and effectively to promote further agricultural development (Widaa and Saeed, 2008). Recycling of wastewater has emerged as a realistic option to overcome problems related to water shortages and its adverse environmental impacts. However, water-scarce countries will have to rely more on the use of wastewater resources to partly alleviate water scarcity (Qadir et al., 2007). Wastewater reuse could free huge amounts of fresh water currently used for irrigation and make this resource available to meet the growing needs for fresh water for domestic uses.

Municipal wastewater is marginal quality water because of the associated health hazards. It is mainly comprised of $99.9 \%$ water together with relatively small concentrations of suspended and dissolved organic and inorganic solids (Pescod, 1992). Wastewater is needed suitable pre-use treatment and appropriate soil-water-crop management strategies when used for irrigation (Qadir et al., 2007). 
Water quality refers to the characteristics of water supply that will influence its suitability for specific use. Quality is defined by certain physical, chemical and biological characteristics as stated by Ayers and Westcot (1985). Scherer et al, (1996) reported that water quality for irrigation purposes is determined by its salt content. They also stated that the analysis of water for irrigation should include the cations: calcium, magnesium, and sodium, and anions; bicarbonate, carbonate, sulfate, and chloride. Water high in $\mathrm{N}$ can cause quality problems in crops such as barley and sugar beets and excessive vegetative growth in some vegetables (Bauder et al., 2011).

In Sirte City substantial quantities of wastewater are usually discharged to Mediterranean Sea. This amount of water increases day by day due to the increase of population and industrial sector in such towns, so planners and authorities should thinking seriously to find safe disposal of this water instead of to be dumped in the sea. Reuse of this water in Agriculture represents one of safe disposal solution. This study specifically aims to assess the efficiency of the wastewater treatment plant at Sirte city and to investigate the quality of treated wastewater for irrigation purposes.

\section{MATERIAL AND METHODS}

The study was conducted at wastewater treatment plant of Sirte city which located at $31.21^{\circ} \mathrm{E}$, and $16.59^{\circ} \mathrm{N}$, Libya. The area is characterized by $14.1 \mathrm{C}^{\circ}$ as minimum temperature and $28.2 \mathrm{C}^{\circ}$ as maximum, while the annual average wind speed is 5 knot and the annual average rainfall is $20 \mathrm{~mm}$.

Composite waste water samples were taken from the effluent before entering the treatment plant and at the final treatment point during November 2012. Samples were taken every two hours starting at 8.00 am and ending at 4 pm during the day. The bottles used for sample collection were cleaned with hot water and suitable detergent, which rinsed with hot water to remove all traces of detergent, and finally were sterilized in an autoclave. The collected samples were brought to the laboratory, filtered and the analysis was done for the determination of bicarbonate and carbonate $\left(\mathrm{HCO}_{3}{ }^{-}\right.$and $\left.\mathrm{CO}_{3}{ }^{\circ}\right)$ ions, sulfate $\left(\mathrm{SO}_{4}{ }^{2}\right)$, chloride $\left(\mathrm{Cl}^{-}\right)$, nitrate $\left(\mathrm{NO}_{3}^{-} \mathrm{N}\right)$, phosphors $(\mathrm{P})$, other major and minor nutrients and heavy metals according to the methods described by Gupta (2007). Also the analysis included $\mathrm{pH}$, electrical conductivity (EC) and (B). SAR and adjSAR were calculated using the following equations according to Ayers and Westcot (1985):

$$
\begin{gathered}
S A R=\sqrt{\frac{N a}{\frac{C a+M g}{2}}} \\
\operatorname{adjSAR}=\sqrt{\frac{N a}{\frac{C a+M g}{2}}[1+(8.4-p H c)]}
\end{gathered}
$$


Where $\mathrm{Na}, \mathrm{Ca}$ and $\mathrm{Mg}$ are in meq/l and $\mathrm{pHc}$ was measured using the following equation as stated by Ayers and Westcot (1985):

$$
\mathrm{pH}_{\mathrm{c}}=\left(\mathrm{pK}_{2}-\mathrm{pK}_{\mathrm{c}}\right)+\mathrm{p}(\mathrm{Ca}+\mathrm{Mg})+\mathrm{p}(\mathrm{A} 1 \mathrm{~K})
$$

The treatment efficiency in wastewater treatment plant of Sirte city was evaluated using the average values of influent parameters before treatment as (input), and the average values after treatment as (output) using the following equation according to Duangporn et al. (2009):

$$
\text { Efficiency } \%=\frac{\text { input }- \text { output }}{\text { input }} \times 100
$$

The success of the process, determined by measuring the size of which indicate the quantity of treated wastewater at the exit, as well as water quality, which leads to the entrance facility for treatment. The relationship between these parameters, at the entrance and exit process in order to obtain data on the same level of success of implementation, is called the degree of efficiency of waste water.

\section{RESULTS AND DISCUSSION}

The parameters $\mathrm{EC}, \mathrm{SAR}, \mathrm{N}, \mathrm{Mg}, \mathrm{SO}_{4}, \mathrm{HCO}_{3}$ and $\mathrm{P}$ of wastewater effluent before and after treatment were detected and used to evaluate the treatment plant efficiency (Table 1). The result showed a great variation in purification of the wastewater constituents. The highest efficiency $(33.45 \%)$ was recorded for bicarbonate $\left(\mathrm{HCO}_{3}\right)$ ions and the lowest one for phosphorus (3.16\%). On the other hand, $\mathrm{pH}$ and $\mathrm{Cl}$ values revealed increment after treatment, (Figures1, and 3 ). This results may be attributed to absent or ineffective monitoring system, unskilled labors, weather conditions, weeds and sedimentation (Ball and Widaa, 2013). The increased percentage of $\mathrm{Cl}$ after treatment may be attributed to the added chloride material before the final stage as a part of treatment processes. In the same time no noticed variation in the K values (Figure 2).

As presented in Table(2), the quality of Sirte treated wastewater in comparison with FAO standards for irrigation water, showed that the concentrations of $\mathrm{EC}, \mathrm{NO}_{3}-\mathrm{N}$, and $\mathrm{Cl}$ and $\mathrm{SO}_{4}$ ions were exceeded the restriction sever level of the FAO standards. Also, the values of $\mathrm{Co}, \mathrm{Cr}, \mathrm{Mn}$ and Mo ions exceeded the levels of the FAO standards (Table 3). The values of $\mathrm{pH}$ (figure 1), SAR, adj.SAR (Figure 4), Boron (Table 2), calcium, magnesium and other trace elements (Table 3 ) were found to conform to FAO standards for irrigation water (Ayers and Westcot, 1985). The increasing levels of previous mentioned parameters may be due to the variations in the sources of 
J. Adv. Agric. Res. (Fac. Agric. Saba Basha)

Table 1: The monitored parameters and purification efficiency of Sirte treatment plant

\begin{tabular}{lcccc}
\hline \multicolumn{1}{c}{ Parameter } & Unit & $\begin{array}{c}\text { Before } \\
\text { Treatment }\end{array}$ & $\begin{array}{c}\text { After } \\
\text { Treatment }\end{array}$ & Efficiency \% \\
\hline EC & dS/m & 4.25 & 3.654 & 0.014 \\
SAR & Indicator & 6.73 & 5.83 & 13.37 \\
$\mathbf{N}$ & $\mathrm{mg} / \mathrm{l}$ & 488 & 403 & 17.42 \\
$\mathbf{C a}^{+2}$ & $\mathrm{mg} / \mathrm{l}$ & 200 & 180 & 10.00 \\
$\mathbf{M g}^{+2}$ & $\mathrm{mg} / \mathrm{l}$ & 122 & 109 & 10.66 \\
$\mathbf{S O}_{\mathbf{4}}{ }^{+}$ & $\mathrm{mg} / \mathrm{l}$ & 787 & 576 & 26.81 \\
$\mathbf{H C O}_{3}{ }^{-}$ & $\mathrm{mg} / \mathrm{l}$ & 293 & 195 & 33.45 \\
$\mathbf{P}$ & $\mathrm{mg} / \mathrm{l}$ & 1.012 & 0.98 & 3.16 \\
\hline
\end{tabular}

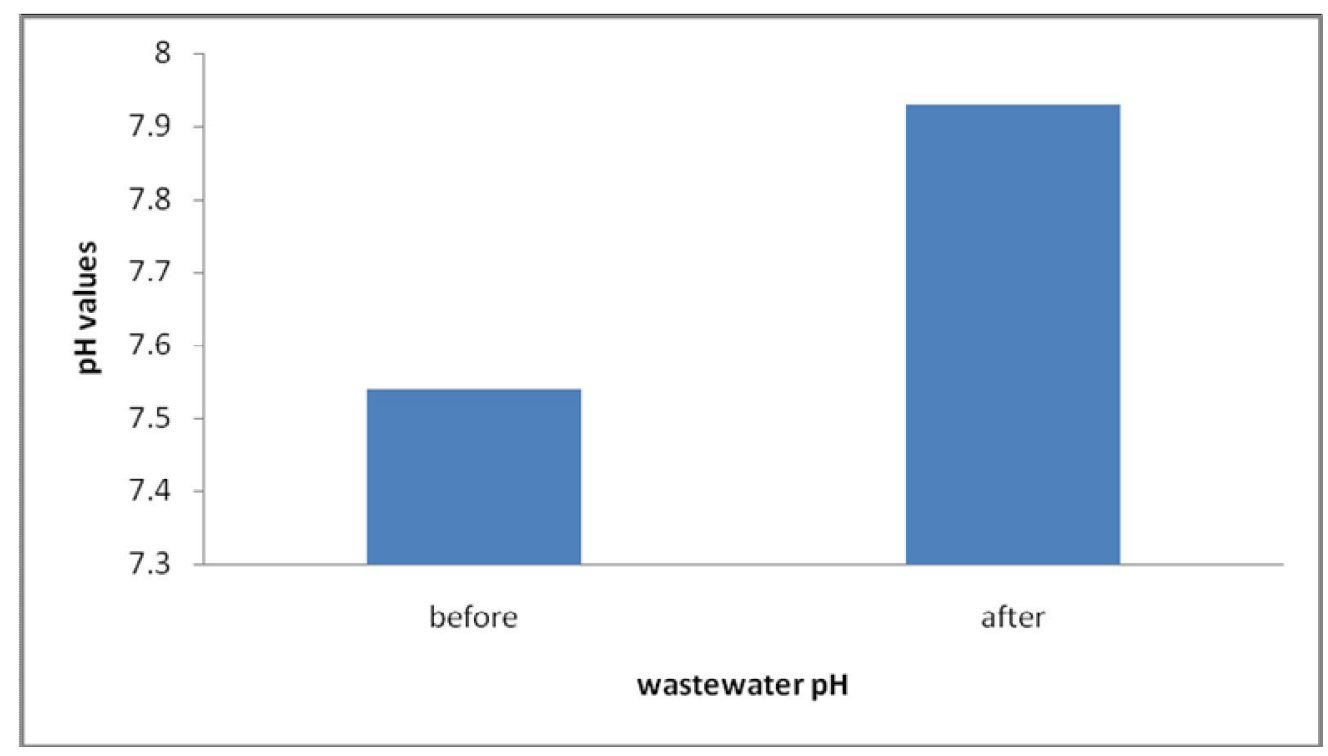

Figure 1: $\mathrm{pH}$ values before and after wastewater treatment 


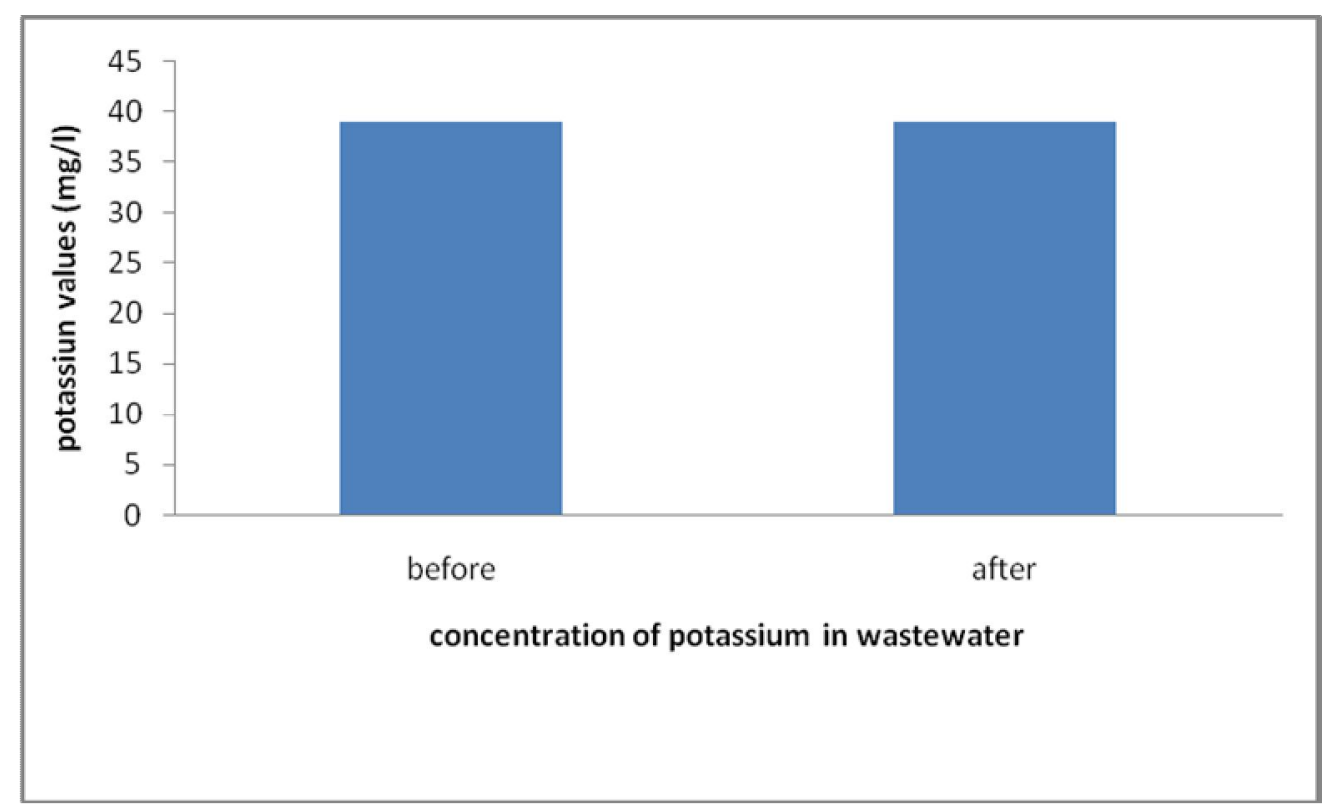

Figure 2: Concentration of Potassium before and after wastewater treatment

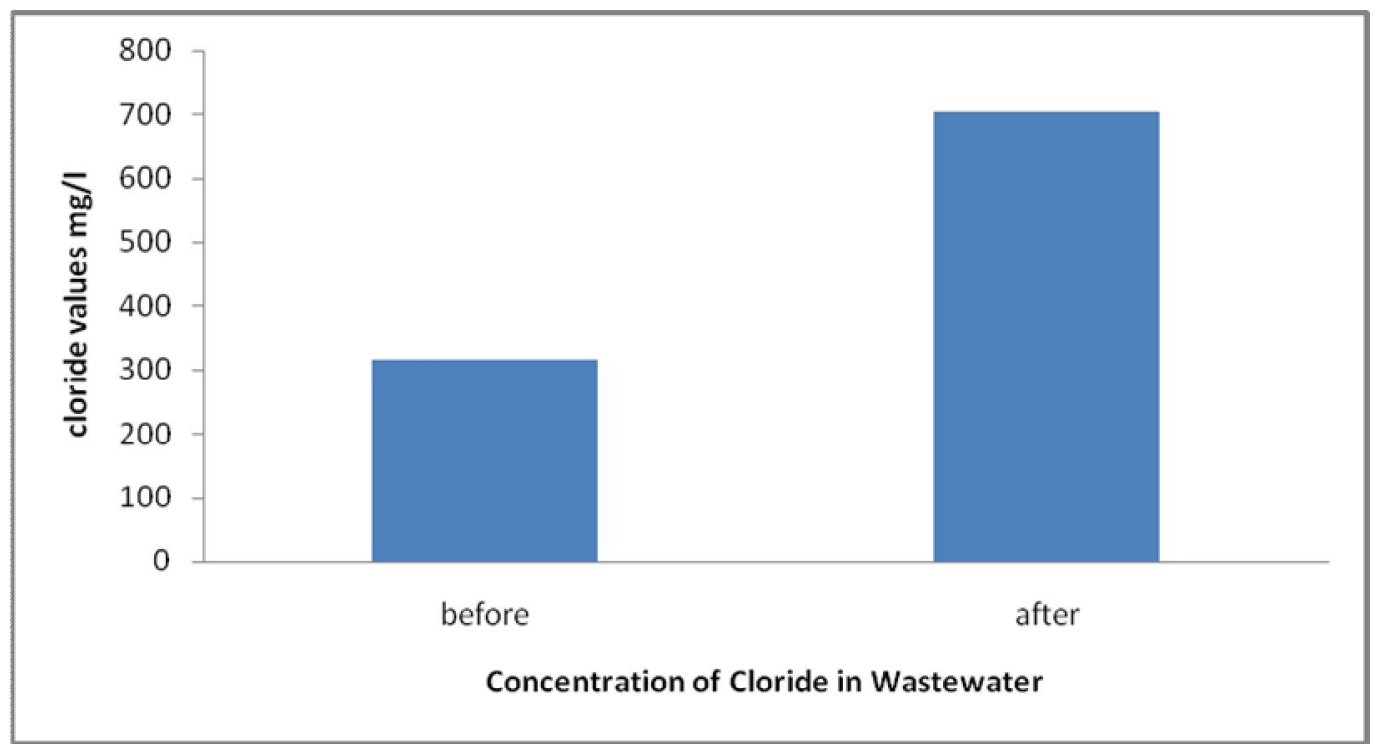

Figure 3: Concentration of chloride before and after wastewater treatment 
wastewater, as well as the addition of chloride after treatment to control microorganism in wastewater. This result supported by Commission on Geosciences Environment and Resources (1996).

Table 2: The parameters of Sirte treated wastewater in comparison with FAO standards for irrigation water

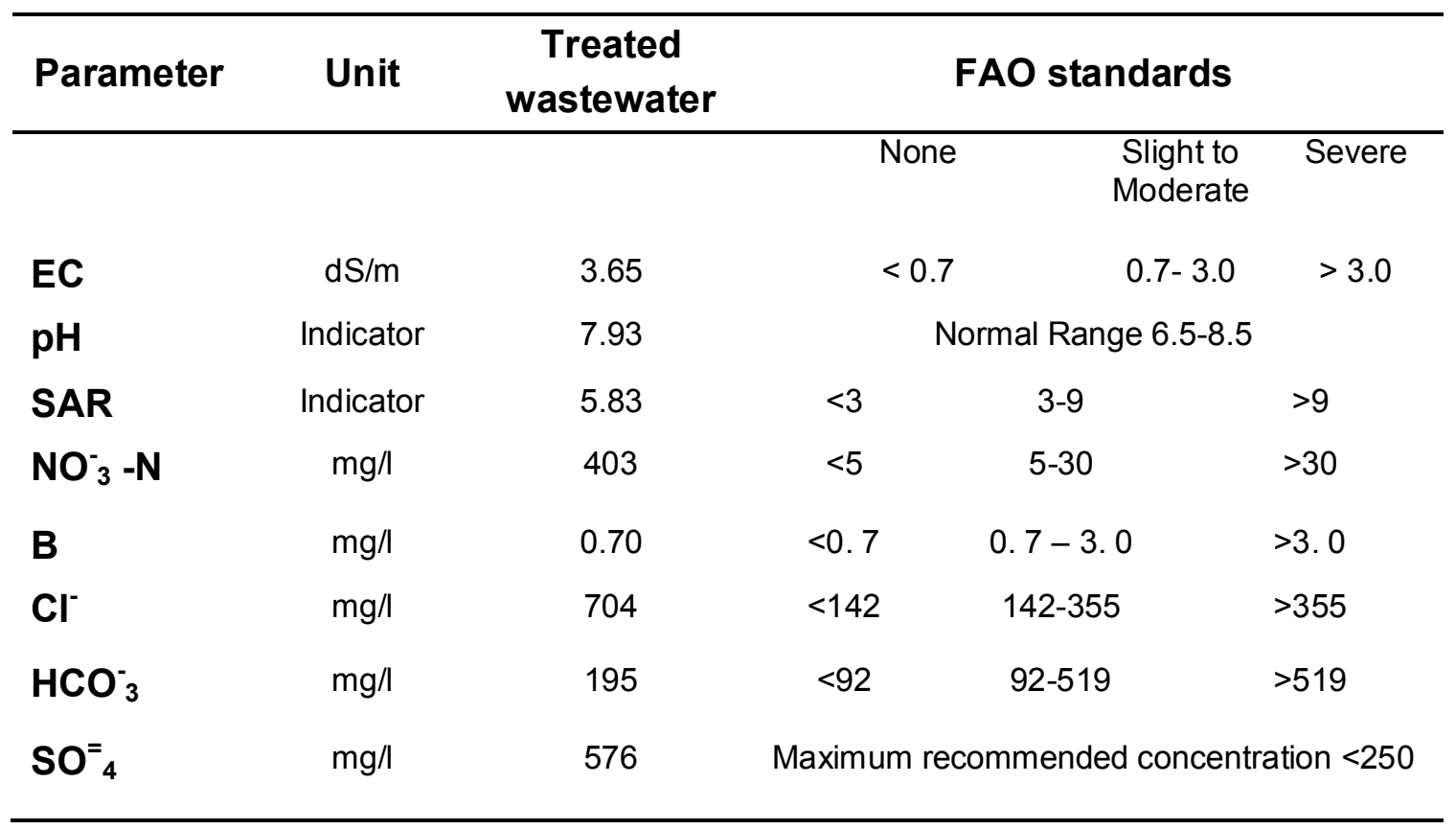


Table 3: The concentration of different element in Sirte treated wastewater in comparison with FAO standards for irrigation water

\begin{tabular}{lccccc}
\hline Element & Symbol & Unit & Sirte & $\begin{array}{c}\text { FAO } \\
\text { standards }\end{array}$ & $\begin{array}{c}\text { Exceeding } \\
\text { Amount }\end{array}$ \\
\hline Mercury & $\mathrm{Hg}$ & $\mathrm{mg} / \mathrm{l}$ & 0.02 & 0.05 & \\
Calcium & $\mathrm{Ca}$ & $\mathrm{meq} / \mathrm{l}$ & 9.00 & 10.0 & \\
Magnesium & $\mathrm{Mg}$ & $\mathrm{meq} / \mathrm{l}$ & 10.0 & 5.00 & \\
Cobalt & $\mathrm{Co}$ & $\mathrm{mg} / \mathrm{l}$ & 0.06 & 0.05 & +0.01 \\
Chromium & $\mathrm{Cr}$ & $\mathrm{mg} / \mathrm{l}$ & 0.40 & 0.10 & +0.30 \\
Copper & $\mathrm{Cu}$ & $\mathrm{mg} / \mathrm{l}$ & 0.03 & 0.20 & \\
Iron & $\mathrm{Fe}$ & $\mathrm{mg} / \mathrm{l}$ & 0.60 & 5.00 & \\
Silver & $\mathrm{Ag}$ & $\mathrm{mg} / \mathrm{l}$ & 0.06 & 2.50 & \\
phosphorus & $\mathrm{P}$ & $\mathrm{mg} / \mathrm{l}$ & 0.98 & 3.70 & \\
Manganese & $\mathrm{Mn}$ & $\mathrm{mg} / \mathrm{l}$ & 6.00 & 0.20 & +5.80 \\
Molybdenum & $\mathrm{Mo}$ & $\mathrm{mg} / \mathrm{l}$ & 0.05 & 0.01 & +0.04 \\
Nickel & $\mathrm{Ni}$ & $\mathrm{mg} / \mathrm{l}$ & 0.04 & 0.20 & \\
Lead & $\mathrm{Pd}$ & $\mathrm{mg} / \mathrm{l}$ & 0.03 & 5.00 & \\
Selenium & $\mathrm{Se}$ & $\mathrm{mg} / \mathrm{l}$ & 0.02 & 0.02 & \\
Zinc & $\mathrm{Zn}$ & $\mathrm{mg} / \mathrm{l}$ & 0.01 & 2.00 & \\
\hline
\end{tabular}

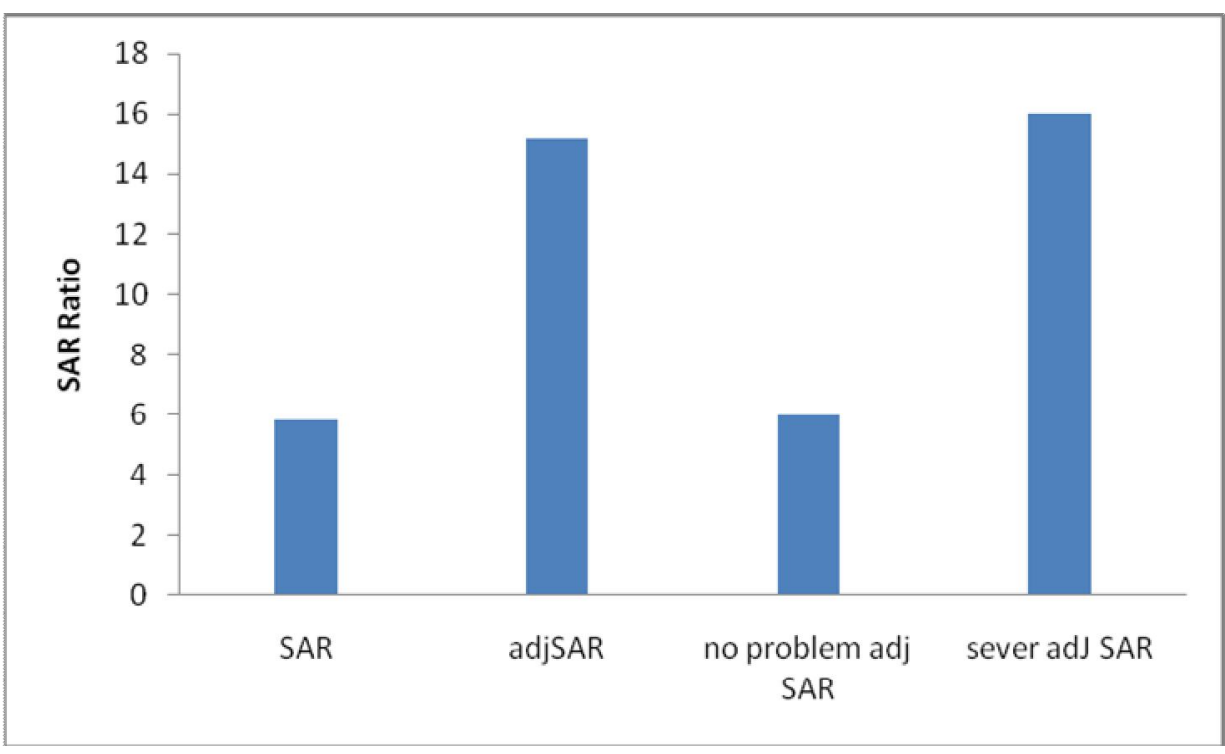

Fig. 4: Comparison of SAR and adj. SAR of treated wastewater with permissible levels of the FAO irrigation water standards 


\section{CONCLUSION}

From standpoint of that irrigation water quality refers to its suitability for use, the Sirte treated wastewater according to the report of Ayers and Westcot (1985); it can be classified as saline water. These because the electrical conductivity (EC) is exceeding the permissible level as recommended by FAO for irrigation water and at the same time lowers values of bicarbonate and calcium were recorded. The toxicity problem is expected when water used to irrigate crops sensitive to Chloride, Cobalt, Chromium, and Manganese. Also the excessive quantities of nitrate- $\mathrm{N}$ is present, which upset the production or delay the crop maturity (Bauder et al., 2011). Therefore any plan of using Sirte treated wastewater for irrigation purposes need appropriates soil-water-crop management strategies.

\section{REFERENCES}

Ayers, R. S. and D. W. Westcot (1985). Irrig. And Drainage paper29 rev.1 Water quality for agriculture. Food and agriculture organization of the United Nations, Rome, Italy.

Ball, T. M., and A. M. Widaa (2013). Evaluation study about quantity, quality and utilization of treated wastewater in khartoum state. M.Sc. Thesis, University of Khartoum.Online available at: www.uofk.edu.

Bauder, T. A., R. M Waskom, P.L. Sutherland and. J. G. Davis (2011). Irrigation Water Quality. CColorado State University Extension. Fact Sheet No. 0.506. Online available at:www.ext.colostate.edu

Commission on Geosciences, Environment and Resources (1996). Mineral Resources and Sustainability: Challenges for Earth Scientists. National Academy Press, Washington DC, 20001.

Duangporn, K., D. Kanthason and S. Cherdchan (2009). Treatment efficiency in wastewater treatment plant of Hat Yai municipality by quantitative removal of microbial indicators. Songklanakrin J.Sci Technol., 31(5): 567576.

Gupta P. K (2007). Soil, plant, water and fertilizers analysis. Second edition, Agrobios(INDIA).

Pescod, M. B (1992). Wastewater treatment and use in agriculture. irrigation and drainage paper 47, FAO, Rome.

Qadir, M., B.R.Sharma, A. Bruggeman, R. Choukr-Allah and F. Karajeh (2007). Non-conventional water resources and opportunities for water augmentation to achieve food security in water scarce countries.Agricultural Water Management 87: 2-22.

Scherer, T. F., B. Seelig, and D. Franzen (1996). Soil water and plant characteristics important to irrigation. Journal of North Dakota State University of Agriculture and Applied Science, 66: 231-7881. 
Widaa, A. M. and A. B. Saeed (2008). Impact of using treated wastewater for irrigation on soil chemical properties, plant growth and forage yield. University of Khartoum journal of Agricultural Science, 16 (1): 75-87.

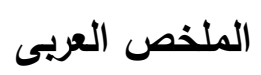

تقيم كفاعة المعالجه فى محطة معالجة المياه العادمة وملائمة المياه المعالجة

$$
\begin{aligned}
& \text { لأغراض الري في مدينة سرث بليبيا } \\
& \text { رمضان على ميلاد } \\
& \text { قسم الأراضى والمياه- جامعه سرت - ليبيا }
\end{aligned}
$$

هدفت هذه الدراسة لتقبم كفاءة المعالجه فى محطة معالجة المياه العادمة وجودة مياه الري في مدينة سرت بليبيا، خلال شهر نوفمبر 2012. وقد جمعت عينات المياه العادمة قبل وبعد المعالجة عند الساعة 8 صباحا و 4 بعد الظهر في كل يوم من شهر نوفمبر • واستخدمت طرق قياسية في تجميع و تحليل عينات المياه. و قد أظهرت متوسط قيم كفاءة التتقية نباين فى العوامل المقاسة، حيث كانت أقل و أعلي قيمة للكفاءه هى 3.6 هـ 3.6 و و 33.45

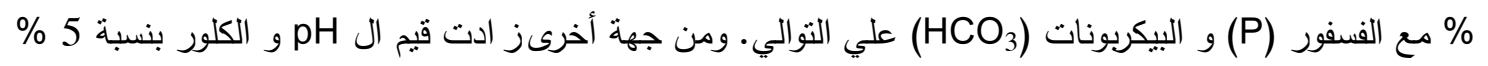

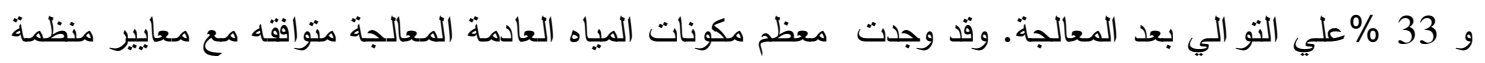
الأغنية و الزراعة (FAO) لمياه الري. بينما كانت قيم التوصيل الكهربى (EC) و الكلور و الكبريتات و الكروم و

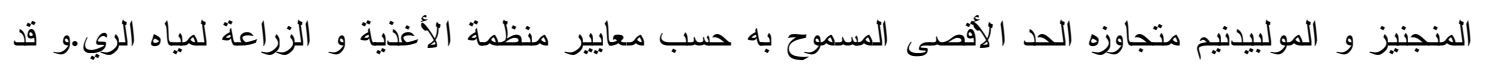

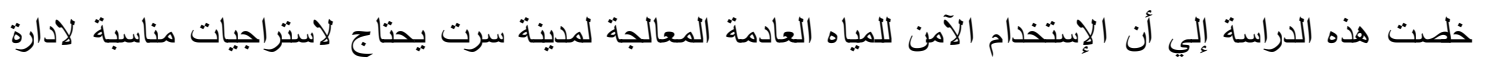
التزبة و المياهو المحصول. 
J. Adv. Agric. Res. (Fac. Agric. Saba Basha) 